\title{
Beyond the academic's dilemma: Transdisciplinary and existential perspectives of re-enchantment
}

\author{
R NAIDOO
}

\begin{abstract}
The purpose of this article is to stimulate debate about the developing paradoxes and dilemmas facing the university academic. This article argues that academics are increasingly being steeped in an inauthentic existence due, at least partly to, egocentrism and sociocentrism. A modest transdisciplinaryexistential analytical framework is applied as an intellectual method to reflect on the prevailing monological perspectives stifling the role of academics, in working towards building a more sustainable future. Using concepts such as the subject, facticity and transcendence, the article investigates the dialectical tensions between some of these monological perspectives and proposes avenues to create new possibilities to progress the role of the academic. The article argues that the multilogical perspectives of transdisciplinary thinking and the empowering perspectives of existential thinking can provide academics with the necessary conceptual tools to transcend egocentrism and sociocentrism. While it is likely that new contradictions will emerge as a result of this synthesis, open-minded academics are urged to ignite their imaginative powers and take up the challenge of creating and acting on new possibilities. A transdisciplinary-existential dialectical approach can provide a richer understanding of present dilemmas in academia and the world, and suggest more satisfying paths to a sustainable future.
\end{abstract}

Keywords: Academic, education, egocentrism, existential philosophy, reenchantment, sociocentrism, transcendence, transdisciplinary, university.

Disciplines: Social psychology, philosophy and critical thinking.

\section{The problem: 'fleeing' from personal responsibility}

The modern academic plays an important role in shaping thought and action in broader society. Through their teaching, they play a key role in developing the attitudes and behaviours of students - the future stewards of society and the planet. Through their research, they are major influencers of the thinking of practitioners in the private sector, state policymakers, non-governmental organisations, research agencies, the media, the general community, and individual citizens. Academics also play an important role in academic citizenship. They are involved in a number of different roles such as guest speakers, journalists, conference organizers, panel members and speakers, journal editors and reviewers,

1. Dr. Rennie Naidoo is a lecturer in Informatics in the Department of Informatics at the University of Pretoria, Pretoria. Email: rennie.naidoo@up.ac.za 
members of community development projects, course developers and evaluators, and internal and external examiners of research reports and dissertations. They also play an important part in informal roles such as the mentoring of colleagues and in discourse with peers and other social groups. However, there is increasing anxiety among scholars about the mechanistic, cookie cutter, assembly line dogma that is dominating the intellectual life of the academic - a situation that is limiting the academic's potency in these various roles - and thus contributing to their growing disenchantment.

Academics are at the forefront of witnessing extraordinary breakdowns and volatility in financial markets, climate change, race relations, religious relations, overpopulation, species extinctions, deforestation, and tense international relations, upheld by prevailing dogmas. As a result, widespread disenchantment, chronic helplessness and a crisis in meaning permeates members of academia's outlook on the world. However, academics can no longer afford to ignore their complicity in propagating prevailing dogmas if they wish to transcend this state of disenchantment and advance a more sustainable future (De Beer, 2014). This article argues that there is an urgent need for more academics to pay attention to the metaphysical significance of this anxiety and face up to it (Yalom, 1980). Taking refuge in short-term pressures or losing the self in everyday activities - in other words, choosing to 'flee' - is no longer an appropriate response (Sartre, 1992:83). In this article, it is argued that the academic's attitude and actions towards the oppressive and suffocating institutional and related pressures, either as hyper-conformity or hyper-cynicism, makes academics at least partly complicit in shaping and even perpetuating some of the complex and challenging crises facing the university and the world, and consequently, humanity's hope of building a more sustainable future.

An attempt will be made to connect two intellectual perspectives that may appear somewhat incompatible: existentialist philosophy and transdisciplinarity. It is shown that these perspectives share a similar conception as far as the human subject is concerned and may be useful in creating possibilities for academics to move beyond current dogmas. A fairly simplistic version of dialectical reasoning will be used as an intellectual method to reflect on the prevailing contradictions at the university. This article also draws on two sociopsychological concepts, egocentrism and sociocentrism (Paul \& Elder, 2005), to understand why many academics are prone to acting in 'bad faitb' (Sartre, 1992:112). The tensions inherent in prevailing perspectives are examined with alternatives to create new possibilities to advance the role of the academic in the university. While it is likely that new contradictions will emerge as a result of any new synthesis, this article closes by urging academics to take up the challenge of inventing and enacting new possibilities.

The rest of the article is organised as follows: Section 2 elaborates on some of the key challenges facing the academic. Section 3 introduces the notion of egocentrism and sociocentrism to describe the limited approach that many individual academics and academic groups are adopting to avoid or to respond to these key challenges. Section 4 presents concepts from phenomenology and existential philosophy to further examine the inauthentic Being of many academics. Section 5 details how academics could dialectically face up to these challenges to arrive at a new transdisciplinary synthesis. Section 6 argues why academics with a transdisciplinary mindset are more likely to transcend the dual problems of egocentrism and sociocentrism. Section 7 caricatures the egocentric and sociocentric tendencies of 'other' academics to show the implications of the prevailing attitudes and behaviours of many academics. Finally, Section 8 (the conclusion) calls for academics to recreate and reinvent 
themselves and their broader community by framing their challenges within a transdisciplinary-existential mindset.

\section{Academia's dilemmas}

Morin (1999:73) describes the current epoch as one that is facing a 'polycrisis' - that is a series of major overlapping and interconnected problems. Yet, many of the areas academics research or teach have become so specialised and fragmented that these crises are being easily overlooked or glossed over. Academics are detached from grappling with serious concerns such as global warming, race relations, religious relations, overpopulation, deforestation, and tense international relations. The present emphasis in the midst of this crisis is rather on market salvation: customers, competition, efficiency and value for money. These areas are elaborated on, next.

First, a number of scholars continue to raise a number of concerns about the hegemonic role of the free market ideology in academia. Gramsci (2012:237) used the term 'hegemony' to describe how a dominant group goes about producing and reproducing a network of institutions, social relations, and ideas. Apple (2013) also expresses concerns about the manner in which cultural, political, and economic forces shape pedagogy and curriculum. He warns against a mono-disciplinary perspective that assumes that knowledge is ahistorical, apolitical and hierarchical.

Academics, Gramsci (2012) maintains, have always played a major role in creating and sustaining such hegemonies. For example, during apartheid, major South African universities served as vehicles for the social and cultural reproduction of this regime of inequality (Soudien, 2010). The veil of distortion and misrepresentation by this system provoked little response from the majority of academics. This legacy still weighs heavily on academics and students. South African academics need to recognise the complexity of transforming the learning experience by acknowledging their personal and their students' different historical, political and social contexts. They need to use their privileged position and the power of freedom of expression to admit to past injustices and expose current injustices. Classroom learning can be more meaningful if academics admit that disciplinary knowledge is never value free or absolute, but dialectic and contested. However, academics today are also aware that the more they dissent against orthodoxies, past and present, the more they can be expected to be demonized by members of the academy or administrators (Furedi, 2004). For example, Stengers (2011) describes how her colleague was sacked by a university for supporting public action against a genetically modified food.

Not surprisingly, a number of scholars argue that the purpose of a modern university is being limited to upholding the free market ideology (Evans, 2004; Giroux, 1983). Academics' dayto-day activities involve competing for contract research and consultancy, attracting corporate and research funding, meeting labour market needs, fostering entrepreneurship among students and colleagues, and developing relationships with their professional and business communities (Nixon Rowland \& Walker, 2010; Ghoshal, 2005). The infiltration of market values is also shaping the priorities and values of universities. Nussbaum (2012) has raised concerns about the closure of philosophy departments and the significant cuts made in the humanities. For example, many universities are seeking to distribute funding away from history, art and literature to areas such as science, economics and accounting. The rationale is that the research on the latter group of disciplines contributes directly to the economy. 
Second, research, a central part to academic life, is also under threat by a 'research market' ideology. The infiltration of the media culture has contributed to the growing importance of global university rankings, which are largely derived from research output. Academics are being incentivised to publish in top-ranked journals to prop up the image of the university, their personal international profile, and for promotion purposes. Academics are also being pressured into obtaining prestigious research grants. Top-ranked journals and powerful research funders get to dictate what counts as rigorous and relevant research. As a result, academics find themselves acceding to approaches that limit and even impose their preferred modes of empirical enquiry and theorising. Furthermore, in keeping with the market ideology, Stengers (2011:2) argues that 'fast, competitive, science' - drawing a parallel with the fast food industry - is replacing 'slow science' as output is increasingly trumping merit and relevance. The research market is further intensifying specialisation and stifling cooperation between disciplines.

Third, a number of scholars are concerned about the increasing level of surveillance they face in an increasingly bureaucratic culture. Ginsberg (2011) argues that a bureaucratic culture of audit and assessment is emerging. At the same time, research and teaching are being subjected to increasing standardisation (Halffman and Radder, 2015). Virtues such as academic freedom are being displaced by the virtue of adhering to administrative bureaucracy. Research is being subjected to targets and measurement. Teaching is being subjected to elaborate student and performance appraisals. Time once given to thought has been increasingly displaced with time spent completing forms. The increasing discipline and control may explain why many academics are hardly ever provoked to react to the crises mentioned above.

Fourth, many academics are concerned that the standards for student intake are being lowered. Broadening access has meant that academics sometimes do not have the resources necessary to maintain standards. Even so, Furedi (2010:121) claims that academics are put under increasing 'pressure' to dumb-down the workload of students and to mark 'positively'. Technocratic and technophilic modes in pedagogical approaches are being used to try to accommodate growing student numbers. However little is known about whether these pedagogies can develop in students the mental habit and power to address the problems they will encounter. Nevertheless, technique appears to be trumping the actual content of knowledge itself. Giroux (2002:448) argues that:

The consequence of the substitution of technology for pedagogy is that instrumental goals replace
ethical and political considerations, result in a loss of classroom control by teachers, make greater
demands on faculty time, and emphasize standardization and rationalization of course
materials.

Freire (2007:34) argues more broadly that:

\begin{abstract}
Education either functions as an instrument which is used to facilitate integration of the younger generation into the logic of the present system and bring about conformity or it becomes the practice of freedom, the means by which men and women deal critically and creatively with reality and discover how to participate in the transformation of their world.
\end{abstract}

Although it seems that academics are indoctrinated to use their learned skills and privileged positions as teachers and researchers to circulate received ideologies (hegemonic), it is not a given that they should become mere technicians and specialists of practical knowledge meant to serve domineering groups. Section 3 introduces the notions of egocentrism and sociocentrism to demonstrate why current thinking about this problem space is limiting. 


\title{
3. The obstacles: egocentrism and sociocentrism
}

Phenomenology and existential psychology perspectives maintain that the inner dimension (Eigenwelt) of existence is shaped by our body, personality, history and future goals, while our social dimension (Mitwelt) is shaped by those we most often interact with (Van Deurzen, 2002:62). Einstein (2003:10) explains the tension between Eigenwelt and Mitwelt, as follows:

\begin{abstract}
A human being is part of the whole, called by us 'universe', a part limited in time and space. He experiences himself, his thoughts and feelings, as something separated from the rest, a kind of optical delusion of his consciousness. This delusion is a kind of prison for us, restricting us to our personal desires and to affection for a few persons close to us. Our task must be to free ourselves from our prison by widening our circle of compassion to embrace all humanity and the whole of nature in its beauty. Nobody is capable of achieving this completely, but the striving for such achievement is in itself a part of the liberation and a foundation for inner security.
\end{abstract}

Summarising from Einstein (2003), it appears that the self is a work-in-progress behaviourally and mentally oriented in two dominant modes of existence, namely the (a) egocentric and (b) the sociocentric modes. These two modes - egocentrism and sociocentrism are seen here to be major contributors to the decline of the academic's intellectual life. These modes of Being can sometimes prevent academics from facing the possibility that their interpretation of reality and experiences might be selective, biased, or misleading. Freud (1975) viewed egocentrism and sociocentrism as fulfilling important emotional ties that shape our Being. These modes can serve to falsify, distort, misconceive, twist or deny reality in order to protect our sense of being (Sumner, 1906). Egocentric tendencies can limit academics' awareness of their own prejudices and viewpoints (Paul \& Elder, 2005). The ego can function self-deceptively, making academics intellectually pretentious, boastful and conceited. Said (1996: 228) therefore challenges academics to look beyond themselves:
You will have other things to think about and enjoy than merely yourself and your domain, and those other things are far more impressive, far more worthy of study and respect than self adulation and uncritical self appreciation. To join the academic world is therefore to enter a ceaseless quest for knowledge and freedom.

Sociocentrism lures academics into conforming to the prevailing views of their peer or social groups, with little or no conscious awareness of what it would be like to rationally decide upon alternative ways to conceptualise these perspectives. Unfortunately, many academics are in awe and seduced by the rituals that promote social solidarity. They live their lives in the trappings of social authority, status and prestige. Serres (1997:193) cautions academics about the danger of academic groupishness and dogma.

\footnotetext{
Sadly, the time has come when the sciences are letting themselves get trapped in the customary subservience of groups who are looking only to perpetuate themselves as a group. Thought can only live free from these constraints.
}

Academics find themselves thrown into a world where they can barely recognise how the ideas promoted in their lessons or research endeavours are being shaped by history and dogmas perpetuated by dominant groups or their in-group. The implications are that academics are developing according to a dominant pattern of thinking - that is, whatever the prevailing orthodoxy expects. Collectively, egocentrism and sociocentrism are serving to systematically objectify and impose limits on the role of the academic. Academics face the urgent task of moving beyond these boundaries, if they intend to reclaim their individual consciousness and innate freedom, and create a sustainable future. The next section examines whether a transcendent mode of existence is possible within such a space. 


\title{
4. Disclosing Being: facticity and transcendence
}

Phenomenology and existential philosophers in particular have examined our fundamental structures of existence and generally agree that human existence is unlike other forms of being. They believe that we are unique in the way that our own Being is an issue for us. For Heidegger, our basic way of being-in-the-world is to also "care" (Sorge); that is, to have concern (Besorge) for entities in the world and (Fürsorge) for others (cited in Johnson, 2000:18). However, our 'Dasein' translated as '(t)here-being' finds itself already thrown in the world; that is, we experience ourselves as already situated in the world, absorbed in relationships with others. Heidegger (cited in Wrathall, 2005:47) describes this absorption in the 'they' as follows:

\begin{abstract}
This being with one another dissolves one's own Dasein completely into the kind of Being of 'the Others', in such a way, indeed, that the Others, as distinguishable and explicit, vanish more and more. In this inconspicuousness and unascertainability, the real dictatorship of the 'they' is unfolded. We take pleasure and enjoy ourselves as they take pleasure; we read, see, and judge about literature and art as they see and judge; likewise, we shrink back from the 'great mass' as they shrink back; we find shocking what they find shocking.
\end{abstract}

Heidegger argues that 'Dasein' loses itself in the averageness of the 'they' where any authentic possibilities for it and the broader community are concealed (Johnson, 2000). Since 'Dasein' cannot withdraw itself from the ontic reality of its existence with others, it must regain sight of the ontological by carefully reflecting on its disposition towards anxiety (van Deurzen, 2002). Anxiety for existentialists refers to a mood or feeling of unease that signals the absurdity of a particular situation. This mood of angst or dread should ideally pressure an individual to face up to their current way of Being (Johnson, 2000). According to Sartre (2007), feeling ill at ease or insecure provides one with the impetus to act freely. Anxiety discloses to 'Dasein' how to set about the paradoxical task of understanding itself and its relationship to the broader community. For this, 'Dasein' needs to cope with the factual realities outside of itself that are acting on the self.

In the everyday being-in-the-world, academics catch glimpses of their inauthentic existence, but ignore these and quickly revert back to the ontic day-to-day activities. A move towards an ontological level of thinking through reflective analysis is required to enable them to face up to their anxiety and use these insights to be more authentic (van Deurzen, 2002). In this reflective analysis, they need to recognise that their present relationships with their peers, students and the broader world community are based on presuppositions - that is, this life that they have taken for granted can change and should change. The task in contemporary society is an arduous one, though. Fromm (2008:2) reminds academics that:

\footnotetext{
The dream of being independent masters of our lives ended when we began awakening to the fact that we have all become cogs in the bureaucratic machine, with our thoughts, feelings, and tastes manipulated by government and industry and the mass communications that they control.
}

Sartre (1992:25) somewhat more optimistically expands this notion of personal freedom and argues that humans exist 'for itself ('pour soi'), and thus are not simply automatons determined by the facts imposed on it by Others. ('Facticity' refers to those properties that the Other establishes and imposes on one's being). The academic that accepts the level of objectification articulated by Fromm (2008) becomes, according to Sartre (1992:18), a thing ('pure immanence'). Following Sartre (2007:22), 'Man's existence precedes his essence'. This implies, among other things, that there is no pre-existing authentic self. The self constructed in academia - the conformist self for instance - was formed through accepting the norms of 
influential Others. The problem with this self is that the academic is reduced to the status of 'the object' in the Other's world.

De Beauvoir (1948:97) explains:

Reduced to pure facticity, congealed in his immanence, cut off from his future, deprived of his transcendence and of the world which that transcendence discloses, a man no longer appears as anything more than a thing among things which can be subtracted from the collectivity of other things without its leaving upon the earth any trace of its absence.

Dupuy (2000:xix) adds to this explanation the limits of a mechanistic worldview:

\begin{abstract}
Because the same technological ambition that gives mankind such power to act upon the world also reduces mankind to the status of an object that can be fashioned and shaped at will; the conception of the mind as a machine - the very conception that allows us to imagine the possibility of (re)fabricating ourselves - prevents us from fulfilling these new responsibilities.
\end{abstract}

For existentialists, accepting absolute objectivity is a form of 'bad faith' (self-deception). Academics are seen to have a choice about how they respond to facticity. Existential philosophers refer to this stance to open ourselves to new possibilities of Being and bringing forth alternative meanings despite the current facticity as "transcendence." One way to bring forth transcendence is by embracing existence as a 'transdisciplinary subject' (Nicolescu, 2005:14). A transdisciplinary perspective can reveal projects that move academics beyond the given conditions in which they find themselves - away from the 'objectified' to Gramsci's (2005:49) 'organic' individual.

\title{
5. The return to prominence of the subject: finding spaces for change
}

A transdisciplinary approach to the global polycrisis calls for a new relation between the subject and object. The old modernist science based on the Cartesian-mechanistic and empiricist paradigms assumed a separation between the subject and object. These paradigms reduced a person to an object - like a tool, a mere instrument, whose significance is dictated to by others - while many postmodernist philosophers reduced a person to a mere 'grammatical subject' (Nicolescu, 2010:21) - lacking agency power such as the freedom to act, insisting that a person is a subject that is socially constructed, and wholly determined by social and political forces.

In contrast, the transdisciplinary view of the subject seems to be consistent with themes in phenomenology and existentialism. Here a person is seen has having responsible agency. As in the philosophy of Heidegger and Sartre, the human condition becomes a key to reality where the subject, as an autonomous self, returns to prominence in grasping and shaping reality. Nicolescu (2010) argues that the new science of quantum theory and biology also characterises reality as non-separability of subject and object. Nicolescu (2010:22) states:

For me "beyond disciplines" precisely signifies the Subject, and, more precisely, the Subject-Object interaction. The transcendence inherent in transdisciplinarity is the transcendence of the Subject. The Subject cannot be captured in a disciplinary camp.

Nicolescu's (2010:28) view of human beings as 'Homo sui transcendentalis' (a person who is born again) has parallels with the existentialist's notion of autonomy and authenticity. Following Sartre (1992:332) then, the authentic self is something all academics have to create for themselves. One way to get closer to achieving authenticity is by rejecting those sociocentric and egocentric tendencies alluded to earlier, which constitute the inauthentic part of the self, and taking responsibility for building a more sustainable future. Section 6 argues that academics should dialectically face up to these conflicts and polarities to arrive at a 
new synthesis, albeit temporary and provisional, to decide what it means to be a responsible academic.

\section{A transdisciplinary dialectic balancing act}

Reasoning dialectically requires that academics enter into a dialogue sympathetically and with an open mind with those that have opposing views. Figure 1 shows the example of the current market dogma colonising the conceptions of students. The current orthodoxy is rather limiting, viewing students as consumers who pay for vocational training that fulfils corporate needs. In other words the balance of the task of the academic is increasingly being tilted in favour of developing a technician and the good employee. As corporate needs become more specialised the notion of a student and the notion of providing a more holistic education that prepares students for the broader needs of society - such as a citizen or a person - are being eroded. One of the major questions the university and academics face is whether they are preparing students adequately to cope with their life challenges? What kind of Being does society need? What kind of Being is society developing?

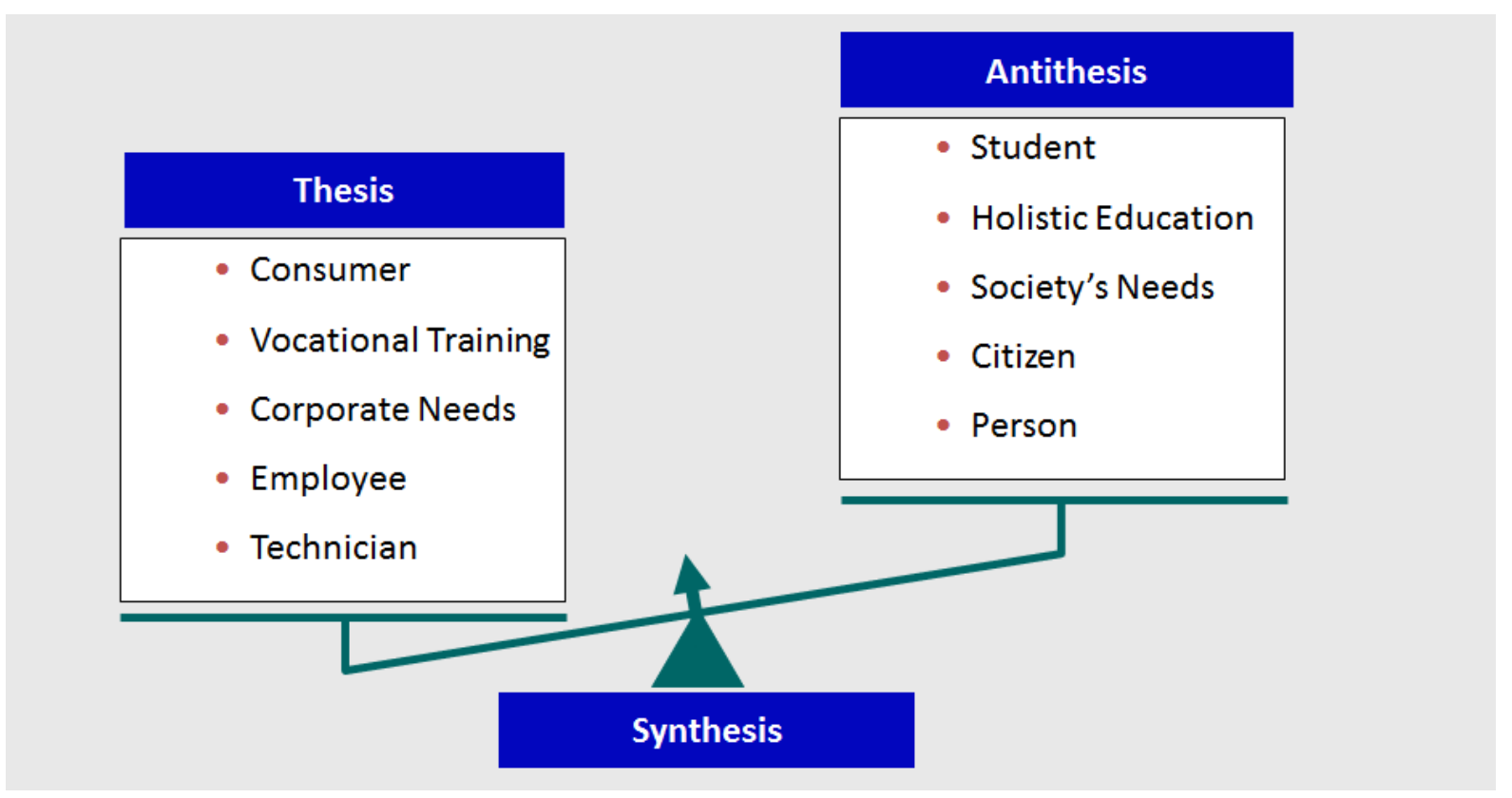

Figure 1: The student - A perpetually developing synthesis

If the education of students is viewed as a technical challenge best left to those in the field of education or economics to resolve, then a simple procedural solution offered by a single discipline may be appropriate. However, educating the student so as to tilt the balance appropriately is a complex problem involving multiple interpretations and calls for a transdisciplinary approach. A wide variety of disciplines from the social sciences, natural sciences, economics and humanities must be brought to bear on the 'wholeness' of this problem. When considering the various conflicting ideas, more than one line of thinking needs to be considered. Given that disciplines in academia have a tendency to generate specialised sub-disciplines that are meant to tackle routine issues, these varied thoughts are likely to come into conflict with each other as soon as they are engaged in a discussion on their strengths and weaknesses. The language of each discipline is not capable of dealing with the multidimensional totality of the problem. Therefore, Mill (1999:22) states: 
that the only way in which a human being can make some approach to knowing the whole of a subject, is by hearing what can be said about it by persons of every variety of opinion, and studying all modes in which it can be looked at by every character of mind. No wise man ever acquired his wisdom in any mode but this.

Paul (1984:11) describes the transdisplinary nature of the dialectic process:

We need emancipatory reason, the ability to reason "across", "between", and "beyond" the neatly marshalled data and narrowed, clear-cut concepts of any given technical domain. Because it cannot presuppose or restrict itself to any one "system" or "technical language" or procedure, it must be dialectical.

Given the inherent complexity and transience of this problem on how a student should be defined, there appears to be no predictable endpoint. In other words, a transdisciplinary mindset appreciates that any synthesis of the notion of the student will always be temporary and provisional. However, a perpetually developing synthesis of the student offers much more hope for the future than the seemingly definable and completed essence of student, balanced in favour of the market or any other dogmatic terms. Other issues within the polycrisis need to be entered into in the same way. Academics must embrace their subjectivity, work towards authenticity, and make a conscious choice to help with this change.

As shown, dialectical thinking within a transdisciplinary perspective can enable academics to reflect and test the presuppositions of factic properties, which, when academics are immersed in the world of the 'they', they take for granted. Transdisciplinary dialectical thinking requires that they test these factic properties - the cause of their anxieties, against opposing views. Similar to existentialism, it places the human being (the subject) at the centre of the making of the self and the discovery of knowledge (Nicolescu, 2005). In addition, it emphasizes bridging the spaces between disciplines as opposed to traversing through a single discipline. The transdisciplinary view of the world is also multilogical as opposed to monological. As such, the transdisciplinary subject is more likely to transcend the problems of egocentrism and sociocentrism. Their 'internal world' can transcend the tendency to view a concern as simply a matter that satisfies their personal desires, values and beliefs, or that of a particular social group. They are also more likely to dissent and doubt the views of their in-group, demonstrate intellectual humility, and create the personal space that can create a rich possibility of options, for dealing with complex problems that serve a broader world. Section 7 caricatures the egocentric and sociocentric tendencies of 'other' academics to show the promise of transcending the problems of egocentrism and sociocentrism.

\section{Beyond the academic's dilemma}

At various times we observe the susceptibility of 'other' academics to egocentric and sociocentric tendencies. These tendencies bring forth different realities for these academics. Figure 2 shows a caricature called "A caricature of the 'other' academic's dilemma", that can help academics perceive their actions from different vantage points. The model plots academics against these two variables: egocentrism and sociocentrism. The exaggerated mentalities and behaviours here can be classified into four main types: 


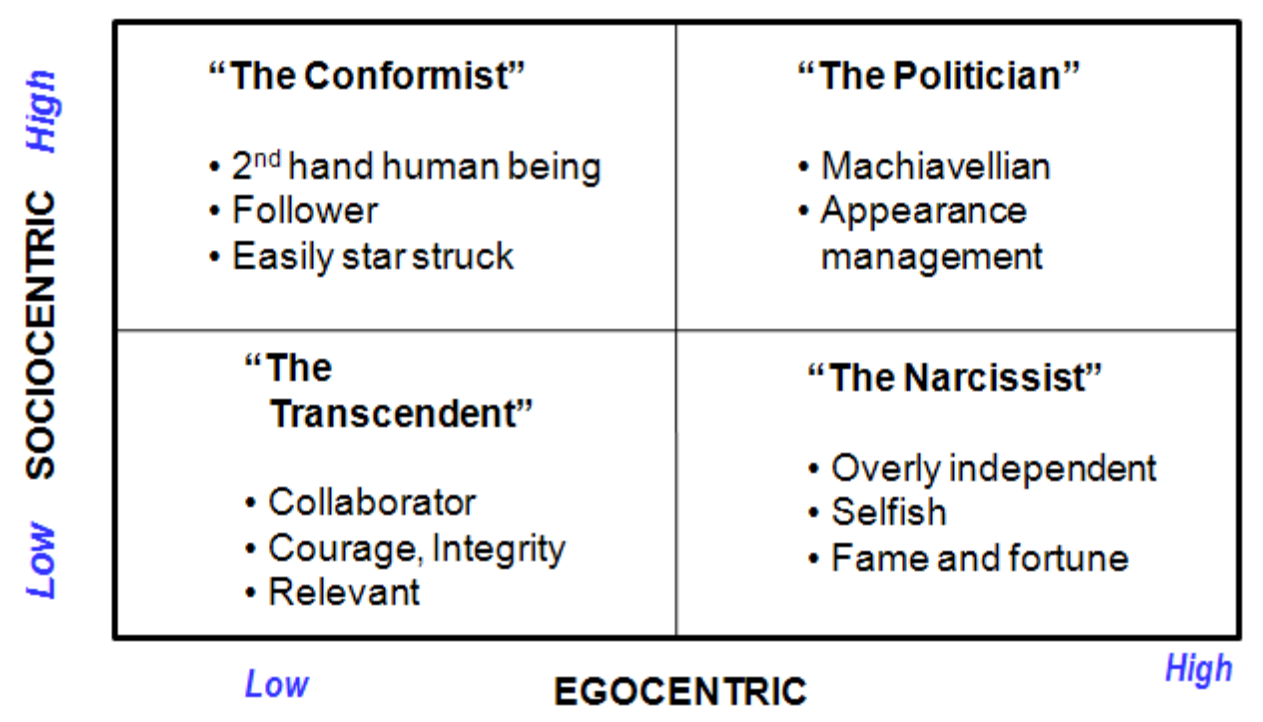

Figure 2: A caricature of the 'other' academic's dilemma

The conformist finds himself high on sociocentrism and low on egocentrism. A follower, this academic is easily star struck by more so-called 'acclaimed academics'. He is an obsequious and pandering individual. The politician finds himself high on sociocentrism and high on egocentrism. Cunning and devious, this academic views others as a means to an end. The narcissist finds himself low on sociocentrism and high on egocentrism. He is excessively independent and works on projects that serve only him. (He loves no one but himself.) The 'ideal type' here is the transcendent. Committed to making a better world and building a more sustainable future, the transcendent is low on sociocentrism and low on egocentrism. As close as it is humanly possible to be authentic, the transcendent has enormous courage and integrity, as well as a high degree of self-awareness. Transcendents have demonstrated excellence in thought and action that they have deliberately cultivated over the years. They are critical, collaborative, reflective transdisciplinary thinkers. Like us, physicist and environmentalist Vandana Shiva is a good example of a transcendent academic. Working closely with farmers oppressed by the state and corporations, she dedicates her life to changing the practice and paradigms of agriculture and food. Consider this profound statement by Shiva (2013:9-10), which - not surprisingly - has a strong existential and transdisciplinary flavour:

\begin{abstract}
An ecological shift entails not seeing ourselves as outside the ecological web of life, it means seeing ourselves as members of the earth family, with the responsibility of caring for other species and life on earth in all its diversity. It creates the imperative to live, produce and consume within ecological limits and within our share of ecological space, without encroaching on the other species and people. It is a shift that recognises that science has already made a paradigm shift from separation to non-separability and interconnectedness, from the mechanistic and reductionist to the relational and holistic.
\end{abstract}

It is unlikely that an academic can be wholly transcendent. It is more likely that given their all too human nature, academics will occupy multiple states at the same time, facing multiple paradoxes and dilemmas in each of these four quadrants. Nevertheless, perhaps this gentle derision will prompt the core of their Being to begin a shift from an overly fragmented and conflicted Being towards a more holistic transcendent. 


\section{The transdisciplinary path to reenchantment: A personal responsibility}

Academics seem to be caught in somewhat of a dilemma that is not perfectly resolvable. If they take a transdisciplinary approach to research and teaching and act by entering into an explicit value discussion, they are condemned by the orthodoxy for illegitimately imposing their ideals on others. If they refuse to embrace a transdisciplinary approach to deal with complex issues, they end up being charged with narrow mindedness and blindness to the injustices that their disciplinary conformity is helping to promote. So where to from here? Academics cannot escape the fact that the role they play is a political one as defined by the research they publish and the manner in which they teach. They are either imprisoning or opening the hearts and minds of their colleagues and students. The ongoing project for academics is to transcend the limits of their personal levels of egocentrism and sociocentrism. For this, academics need to take personal responsiblility. They can elevate their thoughts beyond the strong downward pull of egocentric and sociocentric tendencies by thinking and acting anew. This will go a long way towards reclaiming their freedom and consciousness and the freedom of the Other. Academics will need to temper their disciplinary obsessions by balancing their parochial concerns with broader and interdependent concerns such as ethics, justice and sustainability. Academics have the possibility to recreate and reinvent themselves and their broader community by framing their current projects within a transdisciplinaryexistential mindset. This - the project of becoming Homo sui transcendentalis - offers the academic and humanity the best possibility for re-enchantment, and a sustainable future.

\section{Bibliography}

Apple, M. W. 2013. Education and power. New York: Routledge.

De Beauvoir, S. 1948. The ethics of ambiguity. Ontario: Citadel Press.

De Beer, S. 2014. Michel Serres' multidisciplinary philosophy of information and knowledge. The journal for transdisciplinary research in Southern Africa, 10(1):19-36.

Dupuy, J. P. 2000. The mechanization of the mind: on the origins of cognitive science. New Jersey: Princeton University Press.

Einstein, A. 2003. Bite-size Einstein: Quotations on just about everything from the greatest mind of the twentieth century. London: Gramercy Books.

Evans, M. 2004. Killing thinking: Death of the university. London: Bloomsbury Publishing.

Freire, P. 2007. Pedagogy of the oppressed. London: Bloomsbury Publishing.

Freud, S. 1975. Group psychology and the analysis of the ego. New York: WW Norton \& Company.

Fromm, E. 2008. To have or to be? New York: Continuum International Publishing Group.

Furedi, F. (2004) Where Have All the Intellectuals Gone? Confronting Twentieth Century Philistinism, London: Continuum.

Furedi, F. 2010. Wasted: why education isn't educating. London: Bloomsbury Publishing.

Ghoshal, S. 2005. Bad management theories are destroying good management practices. Academy of management learning E education, 4(1):75-91.

Ginsberg, B. 2011. The fall of the faculty. New York: University Press.

Giroux, H. A. 1983. Theory and resistance in education: a pedagogy for the opposition. South Hadley, MA: Bergin \& Garvey.

TD, 11(2), November 2015, Special edition, pp. 1-12. 
Giroux, H. A. 2002. Neoliberalism, corporate culture, and the promise of higher education: The university as a democratic public sphere. Harvard educational review, 72(4): 425-464.

Gramsci, A. 2012. On hegemony. In Calhoun, C. (Ed.), Contemporary sociological theory. John Wiley \& Sons.

Gramsci, A. 2005. The intellectuals. In Hier, S.P., Contemporary sociological thought: Themes and theories. Toronto: Canadian Scholars' Press Inc.

Halffman, W., \& Radder, H. 2015. The academic manifesto: From an occupied to a public university. Minerva, 1-23.

Johnson, P. A. 2000. On Heidegger. Belmont: Wadsworth Thomson Learning.

Mill, John Stuart. 1999. On liberty. Pleasant Hill: Broadview Press.

Morin, E. 1999. Homeland earth. London, England: Hampton Press.

Nicolescu, B. 2005. Towards transdisciplinary education. The journal for transdisciplinary research in Southern Africa, 1(1):5-15.

Nicolescu, B. 2010. Methodology of transdisciplinarity-Levels of reality, logic of the included middle and complexity. Transdisciplinary journal of engineering E' science, 1:17-32.

Nixon, J., Marks, A., Rowland, S. \& Walker, M. 2001.Towards a new academic professionalism: a manifesto for hope. British Journal of Sociology of Education, 22(2): 227-244.

Nussbaum, M. C. 2012. Not for profit: Why democracy needs the humanities. New Jersey: Princeton University Press.

Paul, R. W. 1984. Critical thinking: Fundamental to education for a free society. Educational leadership, 42(1):414.

Paul, R., \& Elder, L. (2005). A guide for educators to critical thinking competency standards. New York: Foundation for Critical Thinking Press.

Ritzer, G. 2010. Enchanting a disenchanted world: Continuity and change in the cathedrals of consumption. Thousand Oaks: Pine Forge Press.

Said, E. 1996. Identity, authority, and freedom: the potentate and the traveller, in: L. Menand (Ed.) The future of academic freedom. Chicago: The University of Chicago Press.

Sartre, J. P. 1992. Being and nothingness: An essay on phenomenological ontology. New York: Simon \& Schuster Inc.

Sartre, J. P. 2007. Existentialism is a humanism. Yale: Yale University Press.

Serres, M. 1997. The troubadour of knowledge. Ann Arbor: The University of Michigan Press.

Shiva, V. 2013. Making peace with the earth. Auckland Park: Jacana Media.

Soudien, C. 2010. Transformation in higher education: A briefing paper. Pretoria: Development Bank of South Africa.

Stengers, I. 2011. "Another science is possible!" A plea for slow science. In Inaugural lecture of the Willy Calewaert Chair (Vol. 2012).

Sumner, William Graham. 1906. Folkways: A study of the sociological importance of usages, manners, customs, mores, and morals. Boston: Ginn and Company.

Van Deurzen, E. 2002. Existential counselling and psychotherapy in practice. London: Sage.

Wrathall, M. A. 2005. How to read Heidegger. London: Granta Books

Yalom, I. D. 1980. Existential psychotherapy. New York: Basic Books. 